\title{
Employment relations and managerial work: An international perspective
}

Link to publication record in Manchester Research Explorer

\section{Citation for published version (APA):}

Hassard, J., McCann, L., \& Morris, J. (2011). Employment relations and managerial work: An international perspective. In Research Handbook on the Future of Work and Employment Relations/Res. Handb. on the Future of Work and Employment Relat. (1 ed., pp. 150-168). Edward Elgar Publishing Ltd. http://www.eelgar.com/bookentry_main.lasso?id=13751

\section{Published in:}

Research Handbook on the Future of Work and Employment Relations|Res. Handb. on the Future of Work and Employment Relat.

\section{Citing this paper}

Please note that where the full-text provided on Manchester Research Explorer is the Author Accepted Manuscript or Proof version this may differ from the final Published version. If citing, it is advised that you check and use the publisher's definitive version.

\section{General rights}

Copyright and moral rights for the publications made accessible in the Research Explorer are retained by the authors and/or other copyright owners and it is a condition of accessing publications that users recognise and abide by the legal requirements associated with these rights.

\section{Takedown policy}

If you believe that this document breaches copyright please refer to the University of Manchester's Takedown Procedures [http://man.ac.uk/04Y6Bo] or contact uml.scholarlycommunications@manchester.ac.uk providing relevant details, so we can investigate your claim.

\section{OPEN ACCESS}




\title{
8 Employment relations and managerial work: an international perspective*
}

\author{
John Hassard, Leo McCann and \\ Jonathan Morris
}

\section{INTRODUCTION}

The sub-prime financial crisis that erupted in 2007 has once again stimulated widespread concern about the structure, behaviour and ethics of large corporations (especially American corporations). Most discussion has focused at the summit of the organization, on corporate governance, new financial instruments and executive reward systems (Bogle, 2008; Kaplan, 2008; Walsh, 2008). Several analysts have argued that the American 'model' of business has lost much of its appeal following the sub-prime disaster (Capelli, 2009; Whitley, 2009). While not wishing to dismiss these concerns, this chapter suggests that there are also some other major problems taking place on a daily basis in organizational life, further down the corporate hierarchy, that are equally as important as the debates about 'top-end' corporate governance.

In light of recent events in the corporate landscape, which have involved increasingly tough international competition alongside financial crises, scandals and corporate failures, the issue of just how well-run large companies are is of major concern. Amidst this discussion, there is concern in the academic (Green, 2006) as well as the more popular (Bunting, 2004; Fraser, 2001) literature about a distinct decline in the quality of working life for millions of employees in advanced OECD nations. This has long been an issue for blue-collar work but in recent decades it has also become increasingly relevant to white-collar, middle class occupations such as professionals and managers (Cameron et al., 1991; Hochschild, 2003). New organizational forms have involved flatter hierarchies, which squeeze out middle management positions. But has restructuring actually had the desired effects for corporations? Given the frantic work pace that middle managers are often exposed to, organizational errors, inefficiencies and failures may also have become more widespread. Ours is an era which seems to privilege speed and change over structure and stability. But for what purpose? In short, what have these changes in the organizational 
landscape meant for the employment relations that managers have with their employers? And to what extent do these appear to be universal, across mature industrial economies? These are the central concerns of this chapter.

Many studies (especially from the US and UK) have suggested that managerial working life (particularly at the level of middle management which in many cases has been the explicit target of organizational change) has become characterized by heavier workloads and work intensity, broader spans of control, and closer performance monitoring, alongside a marked decrease in promotion prospects (Burke and Cooper, 2000a; Cameron et al., 1991; Cascio, 2002; Worrall et al., 2004). This chapter is based on a detailed review of the extant literature on this theme. In addition, we will summarize an ongoing research project of the authors, which has the evolving employment relationship of managers as a core theme, explored across three large, mature, industrial economies, namely the USA, UK and Japan. Our approach essentially adopts, on the one hand, a more grounded and temporally extensive approach to exploring changes to managerial work and organizational forms, and, on the other, deploying a more genuinely 'critical' theoretical stance - one based on Marxian Labour Process Theory - in our analysis and explanation. Overall, we suggest that problems identified in earlier studies have not been ameliorated. Instead workplace pressures have actually intensified in the last decade. Moreover, similar kinds of restructuring measures, with correspondingly similar forms of work intensification without reward, have been equally felt in countries such as Japan, as well as in the AngloSaxon world.

\section{THEORETICAL UNDERPINNINGS}

Methodologically, our approach is influenced by Barley and Kunda's (2001) approach, using 'grounded and, in this sense, less abstract notions of organizing, [ . . ] developing new languages and images of work.' Theoretically, our point of departure is Labour Process Theory (LPT), a large body of literature that, inspired by Marxian analysis, explores changes to work systems as firms look to achieve better economic returns. The origins of LPT analysis lie with the classic work by Harry Braverman (1974/1998), which described the systematic degradation of craft skills and the rigid separation of planning from execution under the auspices of 'scientific management' (see also Littler, 1982; Taylor, 1911). LPT is primarily concerned with demonstrating how capitalism generates surplus value by close exploration of changes to employment and labour systems within 
workplaces. Following Marx, LPT literature argues that the impetus for capitalism to continually realize profits drives management to ensure the periodic rejuvenation of the forces of production. We would argue that contemporary organizational restructuring is a good example of just this kind of rejuvenation. Although Braverman had little to say about whitecollar work, in recent years LPT authors have attempted to develop this angle in more depth (see Ackroyd, 2009; Thompson and Smith, 2009). We suggest that LPT can also apply to higher-skilled, higher-paid, higherstatus jobs, such as middle management. By following the call of Barley and Kunda (2001), we view middle management as a form of labour, observing the 'dynamic tension' (2001, p. 76) between work and organization. Barley and Kunda argue that work is so closely entwined with organizational forms that the two have to be studied together if we are to develop accurate understandings of the contemporary realities of work and organization (Barley and Kunda, 2001, pp. 76, 77). In particular, our research was designed to explore how changes to organizational structures have led to concomitant changes to the work tasks and working lives of middle managers.

While the currently popular 'varieties of capitalism' (VoC) school (Whitley, 1999; Hall and Soskice, 2001; Amable, 2003; Coates, 2005) is correct in that differences between capitalist economies obviously exist, especially as regards corporate governance, it makes the error that as Barley and Kunda point out - it omits detailed discussion of work practices and organizational forms. VoC writing tends to remain highly abstract and somewhat divorced from the everyday realities of workplaces. VoC authors are often unwilling to provide detail on what actually goes on inside workplaces, especially as this pertains to the human, lived experience of work. The central argument we wish to make, therefore, is that the cultural and institutional differences between nations, while real, can easily be overplayed, resulting in abstract and detached analyses of contemporary capitalism which lack critical detail on the communalities of experience in contemporary capitalism - experience which is often highly problematic for professional and managerial staff.

As such, this chapter explores two main research issues. First, what kinds of changes have large corporations undertaken in recent years and why? Secondly, what impacts have these changes had on managers' working lives? Hassard et al. (2009) for example explored the extent of organizational change, deliberately targeting very large firms with histories of extensive managerial hierarchies. These were firms that might be expected to be under the most pressure to reform their structures and work systems. In doing so Hassard et al. researched a sample of 25 appropriate organizations; nine in the USA (drawn from banking, personnel 
recruitment, auto manufacturing, steel, utilities, local government, healthcare, electronics, engineering); nine in the UK (banking, insurance, autos, steel, utilities, local government, healthcare, engineering and brewing), and seven in Japan (autos, auto components, banking, steel, electronics, engineering, local government), sector-matching the samples. Their research involved interviews with the organizations' senior HR representatives, providing information on the organizational reforms that the firms had carried out over the previous decade and the rationale for introducing them. Subsequently they returned to conduct in-depth interviews with middle managers themselves, in which they were asked to reflect on the ongoing impact of organizational reforms on their work tasks and the quality of their working lives. In all, the study saw 251 research interviews undertaken.

\section{NEW ORGANIZATIONAL FORMS AND MANAGERIAL LABOUR}

There is ample evidence across economies of organizational restructuring to achieve a more 'lean' and flat organizational architecture. Broadly, but not exclusively, this includes three interconnected measures, namely downsizing, de-layering and changing firm boundaries (Morris et al., 2006). The case of downsizing, for example, is demonstrated across economies such as the USA, UK, Japan and elsewhere. This does not imply organizational change per se (in many cases, of course, it just implies cuts in productive capacity) and is not novel, dating back decades. The evidence suggests that it is, in part at least, an overall redesign strategy on the part of organizations.

In the USA, for example, Baumol et al. (2003) noted downsizing across organizations, but particularly in manufacturing. Elsewhere and in other countries, firms have engaged in major cuts to their employment levels. Burke and Nelson (1997), for example, noted that more than 43 million jobs were lost between 1979 and 1996 in the US. This has a considerable, negative knock-on effect for job security (Cameron et al., 1991). Moreover, from the 1990s and beyond, this was no longer concentrated on blue-collar workers but had extended to white-collar workers and managers (Cameron et al., 1991). Empirical studies from the US and UK all point to widespread cost-cuts and worsened pay and conditions and a poorer work environment (Heckscher, 1995; McGovern et al., 1998; Burchill et al., 1999). However, some caution is needed here, as macro national-level data does not always support the managerial downsizing thesis. As Littler and Innes (2004) note, there is a downsizing 'paradox' 
here, explained by 'downsized' managers finding jobs elsewhere in their organizations or in smaller organizations (see also Doogan, 2001 and Froud et al., 2006). Elsewhere in Japan, firms had been far more reluctant to downsize, at least until the 1990s, but both Ahmadjian and Robinson (2001) and Usui and Collignon (1996) reported considerable downsizing in the 1990s, with managers and blue-collar workers similarly affected.

Hassard et al.'s (2009) detailed review of organizational changes and their managerial implications (in the US, UK and Japan) revealed that companies throughout their sample had embarked on significant organizational changes in the late 1990s and early 2000s. Many of the firms had reduced overall headcount as they sought to control costs and to make efficiency savings (although this was not universal as some of them had grown through merger and acquisition strategies). All of the manufacturing firms had outsourced production to cheaper regions (notably China), and this was just as true in Japan as it was in the UK and USA. Decline in employment numbers was usually attritional over many years, most prominently in older established, manufacturing organizations. However, several of the service firms had also made cuts to their employment numbers over recent years. In Japan, employment cuts tended to be carried out in a more considered and conservative, rather than dramatic and radical, manner, involving early retirements with no replacement posts, and recruitment freezes. However, these tactics were also widely used in the US and UK, especially in highly unionized UK organizations. In general, however, the picture was mixed as regards downsizing; not all of the firms had reduced their total number of employees, and some had even grown in size.

De-layering in organizations in perhaps less well documented in the academic literature than downsizing in part because of a relative lack of large-scale databases. However, it has been reported across industries in the US (Batt, 1996; MacDuffie, 1996) and across other countries such as the UK and Japan (Heckscher, 1995; Okubayashi, 1998; Worrell and Cooper, 2001; Littler et al., 2003). This organizational change, together with downsizing, has implications for managerial job security, promotion prospects, work intensification and changing career prospects (Batt, 1996; Grimshaw et al., 2002).

In Hassard et al.'s (2009) study, delaying was more universally found than downsizing. This strategy had been used very widely indeed and it impacted directly on the nature of managerial work and careers. Managerial de-layering was evident across their Japanese sample, but was most prominent at the largest organizations, with one company, for example, having reduced its middle and junior management layers from five to three, motivated by a perceived need to speed up decision-making, but resulting in work intensification, broader task roles, increased spans 
of control and far fewer promotion opportunities. Another had reduced its layers even more dramatically; the company had recently gone through a merger which saw the respective six and seven layers of its legacy companies compressed to just three. The upside appeared to be potentially speedier promotion for promising younger managers, but this was accompanied by the downside of there being fewer posts to apply for.

Widespread de-layering was also evident in the majority of their US sample organizations, with the most radical being in the older and larger organizations. One automotive company, for example, had removed six managerial layers, partly by 'layer-merger', but also by removing some altogether. Moreover, this was accompanied by downsizing at each layer, leading to significant managerial work intensification. A second, large and old, US electronics organization had also dramatically reduced its hierarchy from 14 to seven layers, with a projected target figure of five, while a bank had removed four layers in a shift from a 'hierarchical empire model' to a 'lean matrix one' amidst 'four years of bloodshed'.

In the UK sample, managerial de-layering was also widespread. Delayering was found in both the private and public sectors, although it was more pronounced in the former in terms of the numbers of layers cut. Typically between one and three layers were removed. A number of reasons were given for cutting layers, with flexibility and communications advantages being suggested by a number of respondents. However, in public and private sector alike, cost reductions were cited as the main reason. The layer-merger method was again used frequently.

\section{EXPLORING THE IMPACT OF ORGANIZATIONAL CHANGE ON MANAGERIAL LABOUR}

The new organizational forms do not appear to be transformational, at least in the sense that they are not post-bureaucratic. Indeed, in large organizations bureaucracy persists and there is as much continuity as change. Nevertheless the research evidence does point at least to modified and perhaps hybrid forms, downsized and de-layered. This, inevitably, has implications for the employment relations of managers and the day-to-day nature of managerial work.

Although the complexity of the cross-case and cross-national research makes it difficult to make absolute comparisons, the above overview gives an indication of trends. Large firms have reduced managerial levels in the hierarchy, and cut back on entitlements to managerial staff. A central rationale for developing these flattened and streamlined organizational forms was that managers, and particularly middle ones, have clearly been 
expected to 'do more with less'. Authority has been devolved downwards to middle managers and spans of control expanded outwards. Although redundancies have not been carried out at Japanese firms in Hassard et al.'s study, they were still part of a long-term drip feed of changes to managerial employment, all of which entailed reductions of entitlements and increases in workload. While these Japanese firms were reluctant to engage in the kind of radical changes that were more common in the US and UK, this provided little solace to Japanese managers facing incessantly demanding work pressures. These restructuring measures had concerning, but surprisingly similar impacts on the working lives of managers across countries.

In particular, these changes have impacted upon managers in four broad areas. First, there has been the impact upon security; second, the impact upon the roles that managers carry out; third, the trend towards work intensification for managers and, finally, the impact on promotion prospects and thus career development.

Job security, or at least perceived job insecurity, has been already mentioned as a concern for white-collar and blue-collar workers alike across countries (Heckscher, 1995; Worrell and Cooper, 2001; Grimshaw et al., 2002; Matanle, 2003), an inevitable consequence, perhaps, of corporate downsizing and de-layering.

In Hassard et al.'s (2009) work, job insecurity was pervasive particularly, but not exclusively, in the USA and to a lesser extent in the UK. While none of their Japanese case study firms used compulsory redundancies, they deployed a range of measures to downsize, all short of redundancy and including: a reduction in bonuses: the reassignment and dispatch of managers, or shukko; loss of status; dismissal of temporary and part-time staff; factory closures; reduction in recruitment/hiring freezes and voluntary early retirements. In some companies, middle managers were under considerable pressure to retire early, in one case as young as 45 . Thus, while lifetime employment was still widely practised, it was of a shorter duration and privileged to fewer managers.

Turning to managers' roles, the context of their working lives has, arguably, changed fundamentally in recent years. Organizational changes have been driven by cost-control pressures, and these changes have had clear and unambiguous impacts. Hassard et al.'s (2009) research, for example, illustrates that at more senior levels, managers tended to suggest that change was inevitable, even if they were not always disposed to the prospect of driving ever more effort out of managerial cadres. An HR manager at a US Bank used a memorable phrase to sum this up, declaring that in addition to their everyday 'management' work he needed middle managers to 'move dirt too'. In Japan, the phrase 'player-coach' was used in 
several of the case study companies to describe the same new ethos where managers would be involved in less indirect work and expected to work closely with front-line supervisors on top of their administrative and leadership duties. As the organizations flattened and 'silos' between departments were eradicated, middle managers were meant to have much wider understandings of their businesses - sticking to familiar territory was to be frowned upon, and this territorial expansion was vertical (downwards to supervisors and operatives) as well as horizontal. This entailed major role expansion for managers as their spans of control and spheres of responsibility grew. The HR Manager at a US Bank explained this in detail, again referring to cost pressures as the driver behind this trend to expand middle managers' workloads. He described imperatives to 'squeeze' managerial labour in order to make cost savings.

In order to explain the nature of this incessantly competitive and highly pressured environment, metaphors of a sporting or military nature were often invoked. The sporting metaphor of the 'player-coach' was deployed in all three countries to signal a positive role expansion in the drive to competitive advantage. In contrast, the HR director of a US electronics firm was one of many to invoke military metaphors suggesting that risk-averse middle managers liked to 'camp out' in 'safe territory' rather than embrace the new organizational trend of role expansion. The Director of HR at a UK utilities firm noted similarly that middle managers were increasingly 'under siege' and caught in a 'pincer movement' by their increased workloads and responsibilities.

In Japan, similarly several managers mentioned that Japan had moved into a 'very difficult era', one that was different from the 'era of highgrowth' before recession set in, implying that robust reforms to managerial employment were regrettable but inevitable.

These types of changes in work roles, which were noticeably expanded and extended, have inevitably led to managerial work intensification noted elsewhere (see for, example, Grimshaw et al., 2002). Given this high-pressure environment, almost all of the senior managers interviewed in Hassard et al.'s research mentioned the severe intensity of managerial work. All regarded this as basically inevitable and many expressed misgivings about it. Some were more sanguine and a few even appeared proud to describe the hectic environment, demonstrating how committed they, and their colleagues, were. The HR Director at a US engineering organization used the phrase 'every day is a final exam' to describe his company's harsh working environment. He was hired by the company to provide, in his words, 'more teeth in the HR system', and as such immediately set about installing 'forced ranking' systems. Somewhat wistfully he later went on to admit that these systems 'can be very debilitating'. 
Not only have managers experienced heavier workloads and tougher performance monitoring regimes, for example the Balanced Scorecard and forced rankings, they have also faced acute difficulties with regards career development. The old-style internal labour markets that were a feature of more traditional bureaucratic organizational forms with tall management structures have been thrown into disarray as companies have flattened and de-layered (Osterman, 1996). This has been reported across various economies including the USA (see Osterman, 1996), the UK (Guest and Mackenzie Davey, 1996) and Japan (Lincoln and Nakata, 1997). In Hassard et al.'s research, middle managers faced the prospect of a series of sideways movements, rather than steady progress upwards. This was true even in Japan, which is renowned for seniority-based pay and rewards structures. Overall the practice was generating a chronic problem for management motivation; why should middle managers work increasingly hard when there were so few promotion prospects? Many of their respondents reported that they had become 'stuck fast' in the middle levels of large corporations and that this situation was unlikely to change. Reasons regularly given for this 'motivation gap' were that: (a) the flattening and downsizing of corporate structures meant there were few senior management posts available; (b) as competition for senior positions was now 'massive', managers were pessimistic about their prospects for selection; and (c) as they were already working extremely long hours they questioned the point of exposing themselves to the likelihood of even greater responsibilities.

Managers in their study expressed clear frustrations about the career stagnation and isolation brought on by organizational change. But by far the most severe problem they noted was the sheer size of the workload following cost-cutting via the expansion of their roles. One Japanese manager claimed that due to cutbacks he was now 'doing the work of three kachōs. He went on to rehearse figures for 'annualized working hours', which as our study progressed, appeared to be something of a shared cultural script circulating in large Japanese corporations. Although he suggested the official number of hours worked by a manager in his company was '11 per day' (55 per week), they came to suspect that even this high figure was an underestimation.

\section{DISCUSSION}

While of course there are some substantial international differences in corporate governance, employment relations and organizational traditions across nations, when one looks at lower corporate levels - at the more practical and mundane aspects of working life for managers (their 
employment relationship) - the research findings are strikingly similar. Most studies, including that by the authors, reveal similar policies and features, such as flattened hierarchies, downwardly-devolved responsibilities, heavier workloads for managerial employees, reduced career expectations, and general increases of anxiety, stress, cynicism and detachment among middle managers. While certain areas of the work have become more interesting and possibly more rewarding, the net effect of restructuring has been a considerable worsening of middle managers' quality of working life. We believe this is a major international problem, and one that is not being effectively addressed by senior management.

It is important to bear in mind that, despite the institutional and cultural differences across countries that are emphasized by $\mathrm{VoC}$ authors, all of these nations are mature OECD economies that have been struggling with slower growth and increased competition. In this context it is hardly surprising that organizational changes in large firms headquartered in these economies are enacting similar reforms as they attempt to deliver value. Other recent research points to similar conclusions. For example it is becoming increasingly common for firms to reform or abandon the more generous defined contribution pension schemes in the US and in Japan (Monk, 2009). Largely the same reasons are given for these changes: the intensity of international competition is said to leave senior managers with no choice but to cut employee entitlements.

Discussion of this tougher environment for firms is highly congruent with the longstanding concern in labour process theory about the background drivers of organizational change (Braverman, 1974/1998; Thompson and Smith, 2009). The repeated calls from the senior management community for flatter, more agile, more flexible firms are rooted in the wider condition of the relative slowdown of OECD nations and the need for a revitalization of corporate performance. As these pressures filter into the everyday life of managers working in large firms, the trends in managerial work start to reflect similar, longstanding, trends in the rationalization and intensification of blue-collar work (Braverman, 1974/1998). From an LPT perspective, not only are the tasks of middle management understood as forms of labour, they also appear to be forms of 'sweated' labour, following organizational changes designed to maximize employee effort (Baumol et al., 2003, pp. 261-2). While managerial work has not been 'deskilled' as a traditional LPT interpretation might suggest (in fact, the opposite is the case as managers have been given wider responsibilities and have had to understand the operations of their businesses outside of their traditionally narrow functional specialities) it has certainly been intensified and, in may ways, 'degraded'. Collegiality in particular has collapsed. Middle managers complain of a frantic pace of work 
and hugely expanded workloads. Managerial work has become subject to much tougher monitoring and surveillance. Tangible and intangible rewards for mid-managers have been cut back, especially those associated with traditional internal career ladders.

A remaining question is whether or not these trends are likely to continue. Can middle managers resist or at least influence the trends? Or will the cynicism and resigned compliance of employees lead only to selffulfilling prophecy? Will firms themselves learn to treat their employees with more dignity? A powerful stream of literature argues that corporations are shooting themselves in the foot by pushing their staff to breaking point, and that more civilized treatment can actually result in better performance outcomes. The 'High-Performance Work Systems' (Appelbaum et al., 2000) and 'Responsible Restructuring' (Cascio, 2002) literature makes similar arguments to this effect. There is nothing wrong with the sentiments of these authors. But unfortunately their views are unrealistic because they do not want to admit that corporations often simply don't care enough about these problems to go about the hard work of remedying them. It would take an almost total rethink of corporate life if senior managers were genuinely to attempt to change the culture of overwork and incessant demand. Why would they change long-run habits? There is a long history of sociological work that highlights the mistreatment of workers in large corporations, such as Jackall's (1988) classic work on the moral decrepitude of US corporations, or Kamata's (1983) on the single-minded ruthlessness of the work demands at Toyota. Senior figures in organizations do not care enough about these problems further down the hierarchy. In fact, they embody some of their toughest elements; diary research has demonstrated, for example, that CEOs work an average of over 72 hours per week (Tengblad, 2006). The 'macho' assumption that employees have unlimited time and energy to devote to work is alive and well in contemporary organizations (Hochschild, 2003).

So what are the implications of the analysis? Given the suggestion that change will not come from firms, any transformation away from the culture of normalized intensity would probably have to come from midmanagerial employees themselves. In line with Spicer et al.'s (2009) call for 'critical performativity', we suggest that critically-minded scholars should attempt to 'encourage more progressive forms of management', especially the 'micro-emancipations' that could potentially result from helping managers to consider which forms of behaviour are ethically and practically appropriate in corporate life. This encouragement might involve much more engagement with conventional media outlets, an area where academics have not traditionally been successful. It could certainly involve shifting the focus in MBA teaching towards the subjects of ethics and 
human dignity. As Adler, Forbes and Willmott suggest, in an important overview article which outlines and advocates the traditions of Critical Management Studies (2007, pp. 34-5), 'managers, especially at lower hierarchical levels, often find themselves torn in their loyalties. A critical pedagogy can help [... ] managers to become aware of this contradiction, and help them to reflect on how they can position themselves relative to it.'

The final chapter of Braverman's Labour and Monopoly Capitalism contains a call for the next generation of readers to become engaged in a wider struggle to expose and confront the mistreatment of workers. In the context of managerial labour, this kind of resistance and mobilization is difficult to imagine; managers are major stakeholders in firms and, despite their grievances, actually want their companies to be successful. They have little or nothing to gain from traditional forms of resistance, and have very ambivalent relationships as regards labour unions, for example. But the grievances they described in our research are serious and immediate. We suggest that perhaps the most fruitful avenue of response is to encourage middle managers to use whatever assets they have in order to seek redress in their excessively demanding work lives. One major advantage of managerial work is its autonomy - although almost all of our managers complained about excessive workloads, they did at least have considerable autonomy about how and when they worked. (Several used phrases such as 'there is no-one standing over me with a gun forcing me to work these hours'). With this in mind, we suggest that middle managers should reclaim some of their dignity at work by using some of this autonomy to reconsider the value of their own work practices. This could even lead to improved organizational outcomes as managers at last have some time to think creatively rather than being overwhelmed by immediate pressures. Of course, all of the above is much easier said than done, especially in the current climate of recession and redundancies. In all likelihood, the incessant demands on managerial workers will recede only if those at the top recognize the problem and attempt to address it. But sadly we have no reasons to predict that they will try.

\section{CONCLUSIONS}

In conclusion, we have argued that issues of employment restructuring, cost control and work overload are not restricted to the highly open, flexible and transient Anglo-Saxon 'model' of capitalism. Organizational restructuring has also been significant in Japan, especially given the nearfifteen years of economic stagnation brought on by Japan's own financial crisis in 1990. Substantial changes were visible in our Japanese case study 
organizations, involving the gradual shrinkage of employment numbers, career stagnation for middle managers, and some surprisingly robust tactics of de-layering and 'slimming-down', especially of administrative, or 'non-direct' management positions. This confounds the view, commonly held by those in the institutional theory and 'varieties of capitalism' schools that Japanese firms have been somehow unwilling or unable to restructure in recent years (see for example Witt, 2006). Although the anthropological 'feel' of these Japanese organizations was indeed quite different from that existing in the US and UK cases, the Japanese firms had used similar general tactics of cost control and de-layering. It was also true that organizational change was less dramatic in Japan and that there was a great deal more scepticism about US-style 'off the shelf' consulting 'solutions'. Japanese firms remained wedded to an insider system of corporate governance and tended to be very circumspect about the value of radical change (Dore, 2002; Jacoby, 2005; Robinson and Shimizu, 2006; Witt, 2006; Vogel, 2007).

Nevertheless, the slow, incremental approach to organizational change has exposed Japanese middle managers to precisely the same stresses and traumas as their Western counterparts. In fact, many of the organizational change processes deployed (flattening of hierarchies, changes to pay and reward systems, and widening span of control of middle managers) were essentially the same as those used in the US and UK, and they generated essentially the same effects; heavier workloads, wider responsibilities, and more limited upwards movement for middle managers.

Therefore, in contrast to the 'varieties of capitalism' school, this chapter has argued that similarities across organizations and nations might be more pertinent than their differences. Although we would not deny that 'business systems' differences are in many ways powerful and resilient, we argue also that their importance is frequently overplayed. Our data demonstrate that, when observed from the level of middle managers' personal lives, the contemporary transformations of organizational structure and managerial work have been very similar despite the institutional differences between the Anglo-Saxon and Japanese 'varieties of capitalism'. Moreover the environmental drivers which encouraged large firms to enact organizational changes were essentially identical across our cases. Whether the explanation given in the interviews was one of shareholder value returns (a very popular narrative in US and UK corporations, but not in Japan), or radical increases in competitive pressures (the stock explanation in all three countries), the fundamental impetus for organizational change was top managements' desire to tighten cost control.

Overall the findings from our comparative study of the contemporary nature of managerial work confirm the pessimistic view of earlier literature 
on job satisfaction and work-life (im)balance. While some of the new work tasks of middle managers are more engaging and more intrinsically rewarding than many traditional tasks, the root cause of managers' distress is simply the sheer volume of the workload - practically all stated that it had grown substantially over the last decade. We suggest that this heavy workload necessitates excessive work speed and work intensity which creates considerable anxiety and stress. This also has the knock-on effect of creating certain negative organizational outcomes as the quality and consistency of managerial work inevitably suffers. While many managers noted that their work tasks had become more interesting and engaging following organizational change, these positives were outweighed by complaints about low morale and motivation, overwhelming workload and, in many cases, disaffection and cynicism about top management strategies. Middle managers, because of their ambivalent role as both managers and 'the managed', tended not to resist top management, and approached their increased challenges with an air of resigned compliance.

\section{NOTE}

* This research was a six-year qualitative study of organizational and HRM strategy in 25 large organizations and 200 middle managers in the three countries. It has been reported extensively; see for example, Morris et al., 2006; 2008; 2011; McCann et al., 2008; 2010; Hassard et al., 2009).

\section{REFERENCES}

Ackroyd, S. (2009), 'Labour process theory as "normal science"', Employee Responsibilities \& Rights Journal, 21(3), 263-72.

Adler, P., L. Forbes and H. Willmott (2007), 'Critical management studies', The Academy of Management Annals, 1, 119-79.

Ahmadjian, C.L. and P. Robinson (2001), 'Safety in numbers: downsizing and destitutionalization of permanent employment in Japan', Administrative Science Quarterly, 46, 622-54.

Amable, B. (2003), The Diversity of Modern Capitalism, Oxford: Oxford University Press.

Appelbaum, E., T. Bailey, P. Berg and A.L. Kalleberg (2000), Manufacturing Advantage: Why High-Performance Work Systems Pay Off, Ithaca, NY: Cornell University Press.

Barley, S. and G. Kunda (2001), 'Bringing work back in', Organization Science, 12, 76-95.

Batt, R. (1996), 'From bureaucracy to enterprise? The changing jobs and careers of managers in telecommunication service', in Osterman, P. (ed.), Broken Ladders: Managerial Careers in the New Economy, New York: Oxford University Press, pp. 55-86.

Baumol, W.J., A.S. Blinder and E.N. Wolff (2003), Downsizing in America: Reality, Causes, Consequence, New York: Russell Sage Foundation.

Bogle, J. (2008), 'Reflections on CEO compensation', Academy of Management Perspectives, 22(2), 21-5.

Braverman, H. (1974/1998), Labour and Monopoly Capitalism: The Degradation of Work in the Twentieth Century, London: Monthly Review Press. 


\section{Research handbook on the future of work and employment relations}

Bunting, M. (2004), Willing Slaves: How the Overwork Culture is Ruling Our Lives, London: HarperCollins.

Burchill, B.J. et al. (1999), Job Insecurity and Work Intensification, York: Joseph Rowntree Foundation.

Burke, R.J. and C.L. Cooper (2000a), 'The new organizational reality: transition and renewal', in R.J. Burke and C.L. Cooper (eds), The Organization in Crisis: Downsizing, Restructuring, and Revitalization, Oxford: Blackwell.

Burke, R.J. and C.L. Cooper (eds) (2000b), The Organization in Crisis: Downsizing, Restructuring, and Revitalization, Oxford: Blackwell.

Burke, R.J. and D.L. Nelson (1997), 'Downsizing and restructuring: lessons from the firing line for revitalising organizations', Leadership and Organization Development Journal, 18, 325-34.

Cameron, K.S., S.J. Freeman and A.K. Mishra (1991), 'Best practices in white-collar downsizing: managing contradictions', Academy of Management Executive, 5, 57-73.

Capelli, P. (2009), 'The future of the US business model and the rise of competitors', Academy of Management Perspectives, 23, 5-10.

Cascio, W.F. (2002), 'Strategies for responsible restructuring', Academy of Management Executive, 16, 80-91.

Coates, D. (ed.) (2005), Varieties of Capitalism, Varieties of Approaches, Basingstoke: Palgrave.

Doogan, K. (2001), 'Insecurity and long-term employment', Work, Employment and Society, 15, 419-41.

Doogan, S. and R. Steward (1990), 'What is happening to middle management?', British Journal of Management, 1, 3-16.

Dore, R. (2002), 'Stock market capitalism and its diffusion', New Political Economy, 7, $115-21$.

Fraser, J.A. (2001), White-Collar Sweat-Shop: The Deterioration of Work and its Rewards in Corporate America, New York: W.W. Norton.

Froud, J., S. Johal, A. Leaver and K. Williams (2006), Financialization and Strategy: Narrative and Numbers, Abingdon: Routledge.

Green, F. (2006), Demanding Work: The Paradox of Job Quality in the Affluent Economy, Princeton, NJ: Princeton University Press.

Grimshaw, D.H. Beynon, J. Ruberty and K. Ward (2002), 'The restructuring of career paths in large service sector organizations: delayering, upskilling and polarisation', The Sociological Review, 50, 89-116.

Guest, D. and K. Mackenzie Davey (1996), 'Don't write off the traditional career', People Management, 22 February, 22(5).

Hall, P.A. and D. Soskice (eds) (2001), Varieties of Capitalism: The Institutional Foundation of Comparative Advantage, Oxford: Oxford University Press.

Hassard, J., L. McCann and J. Morris (2009), Managing in the Modern Corporations: Reintensification of Managerial Work in the USA , UK and Japan, Cambridge: Cambridge University Press.

Heckscher, C. (1995), White Collar Blues: Management Loyalties in an Age of Corporate Restructuring, New York: Basic Books.

Hochschild, A.R. (2003), The Second Shift, London: Penguin.

Jackall, R. (1988), Moral Mazes: Inside the World of Corporate Managers, Oxford: Oxford University Press.

Jacoby, S.M. (2005), The Embedded Corporation: Corporate Governance and Employment Relations in Japan and the United States, Princeton, NJ: Princeton University Press.

Kamata, S. (1983), Japan in the Passing Lane: An Insider's Account of Life in a Japanese Auto Factory, London: Allen \& Unwin.

Kaplan, S.N. (2008), 'Are US CEOs overpaid? A response to Bogle and Walsh', Academy of Management Perspectives, 22(3), 28-34.

Lincoln, J. and Y. Nakata (1997), 'The transformation of the Japanese employment system: nature depth and origins', Work and Occupations, 24, 33-5. 
Littler, C. (1982), The Development of the Labour Process in Capitalist Societies, London: Heinemann.

Littler, C. and P. Innes (2004), 'The paradox of managerial downsizing', Organization Studies, 25, 1159-84.

Littler, C. and R. Wisener and R. Dunford (2003), 'The dynamics of delayering: changing management structures in three countries', Journal of Management Studies, 40, 225-56.

McCann, L., J. Hassard and J. Morris (2010), 'Restructuring managerial labour in the USA, UK and Japan: challenging the salience of "varieties of capitalism", British Journal of Industrial Relations, 48, 347-74.

McCann, L., J. Morris and J. Hassard (2008), 'Normalised intensity: the new labour process of UK middle managers after large scale restructuring', Journal of Management Studies, 45, 343-71.

MacDuffie, J.P. (1996), 'Automotive white collar: the changing status and roles of salaried employees in the North American auto industry', in P. Osterman (ed.), Broken Ladders: Managerial Careers in the New Economy', Oxford: Oxford University Press, pp. 81-125.

McGovern, P., V. Hope-Hadley and P. Stiles (1998), 'The managerial career after downsizing: case studies from the leading edge', Work, Employment and Society, 12, 457-77.

Matanle, P. (2003), Japanese Capitalism and Modernity in a Global Era: Refabricating Lifetime Employment Relations, London: Routledge, Curzon.

Monk, A.H.B. (2009), 'The financial thesis: reconceptualizing globalisation's effect on firms and institutions', Competition \& Change, 13, 51-74.

Morris, J., J. Hassard and L. McCann (2006), 'New organizational forms, human resource management and structural convergence? A study of Japanese organizations', Organization Studies, 27, 1485-512.

Morris, J., J. Hassard and L. McCann (2008), 'The resilience of institutionalised capitalism: managing under shareholder capitalism and managerial capitalism', Human Relations, 61, $687-710$.

Morris, J., J. Hassard and L. McCann (2011), 'My brilliant career: boundary-less organizations and unstable careers in the UK, USA and Japan', Journal of Management Studies (forthcoming).

Okubayashi, K. (1998), 'Small headquarters and the reorganization of management', in M. Harukiyo and G. Hook (eds), Japanese Business Management: Restructuring for Low Growth and Globalization, London: Routledge.

Osterman, P. (ed.) (1996), Broken Ladders: Managerial Careers in the New Economy, New York: Oxford University Press.

Robinson, P. and N. Shimizu (2006), 'Japanese corporate restructuring: CEO priorities as a window on environmental and organizational change', Academy of Management Perspectives, 20, 44-75.

Spicer, A., M. Alvesson and A. Karreman (2009), 'Critical performativity: the unfinished business of critical management studies', Human Relations, 62, 537-60.

Taylor, F. (1911), Principles of Scientific Management, New York: Harper \& Row.

Tengblad, S. (2006), 'Is there a new managerial work? A comparison with Henry Mintzberg's study 30 years later', Journal of Management Studies, 43, 1437-61.

Thompson, P. and C. Smith (2009), 'Waving, not drowning. Explaining and exploring the resilience of labour process theory', Employee Responsibilities \& Rights Journal, 21(3), 253-62.

Usui, C. and R. Colignon (1996), 'Corporate restructuring: converging world pattern or societally specific embeddedness?', Sociological Quarterly, 4, 351-78.

Vogel, S.K. (2007), Japan Remodeled: How Government and Industry are Reforming Japanese Capitalism, Ithaca, NY: Cornell University Press.

Walsh, J.P. (2008), 'CEO compensation and the responsibilities of the business scholar to society', Academy of Management Perspectives, 22(2), 26-33.

Whitley, R. (1999), Divergent Capitalisms: The Social Structuring and Change of Business Systems, Oxford: Oxford University Press. 
166 Research handbook on the future of work and employment relations

Whitley, R. (2009), 'US capitalism: a tarnished model?' Academy of Management Perspectives, 23, 11-22.

Witt, M. (2006), Changing Japanese Capitalism, Cambridge: Cambridge University Press.

Worrall, L. and C. Cooper (2001), The Quality of Working Life: the 200 Survey of Managers' Experience, London: Institute of Management.

Worrall, L., C. Parkes and C.L. Cooper (2004), 'The impact of organizational change on the perceptions of UK managers', European Journal of Work and Organizational Psychology, 13, 139-63. 